\section{MUSCULAR STRENGTH AND REGIONAL LEAN MASS INFLUENCE BONE MINERAL HEALTH AMONG YOUNG FEMALES}

\author{
FORÇA MUSCULARE MASSA MAGRA REGIONAL INFLUENCIAM A SAÚDE MINERAL ÓSSEA \\ ENTRE JOVENS MULHERES
}

FUERZA MUSCULARY MASA MAGRA INFLUENCIAN LA SALUD MINERAL ÓSEA ENTRE

JÓVENES MUJERES

\begin{abstract}
Introduction: Strength training is able to stimulate bone tissue metabolism by increasing mechanical stress on the skeletal system. However, the direct relationship is not yet well established among younger women, since it is necessary to describe which strength enhancement level is able to produce effective changes in bone integrity. Objectives: This study analyzed the influence of muscle strength on bone mineral content (BMC) and bone mineral density (BMD) among female college students. Methods: Fifteen women (24.9 \pm 7.2 years) were assessed for regional and whole-body composition by dual-energy $X$-ray absorptiometry (DXA). The one-repetition maximum (1-RM) tests were assessed on flat bench press (BP), lat pulldown (LPD), leg curl (LC), knee extension (KE), and 45 degree leg press (45LP). Linear regression analyzed the relationships of BMC/BMD with regional composition and 1-RM test values. Measures of dispersion and error ( $R^{2}$ adj and SEE) were tested, defining a p-value of 0.05 . Results: The mean value of whole-body BMC was $1925.6 \pm 240.4 \mathrm{~g}$ and the BMD was $1.03 \pm 0.07 \mathrm{~g} / \mathrm{cm}^{2}$. Lean mass (LM) was related to $B M C\left(R^{2}\right.$ adj $=0.86, p<0.01$, and $\left.S E E=35.6 \mathrm{~g}\right)$ and $B M D\left(R^{2}\right.$ adj $=0.46, p<0.01$, $\left.S E E=0.13 \mathrm{~g}\right)$ in the lower limbs (LL). The 1-RM tests in BP were associated with BMC and BMD $\left(R^{2}{ }_{\text {adj }}=0.52, p<0.01, S E E=21.4 \mathrm{~g}\right.$, and $\mathrm{R}_{\text {adj }}^{2}=0.68, \mathrm{p}<0.01, \mathrm{SEE}=0.05 \mathrm{~g} / \mathrm{cm}^{2}$, respectively) in the upper limbs, while the 1-RM tests in $\mathrm{KE}$ were related to $B M C$ and $B M D\left(R^{2}\right.$ adj $=0.56, p<0.01$. SEE $=62.6 \mathrm{~g}$, and $R^{2}{ }_{\text {adj }}=0.58, p<0.01, S E E=0.11 \mathrm{~g} / \mathrm{cm}^{2}$, respectively) in the lower limbs. Conclusions: Hence, the 1-RM tests for multi-joint exercises are relevant to the regional $B M C / B M D$, reinforcing the need to include resistance exercises in training routines with the purpose of improving muscular strength and regional lean mass, thereby ensuring a healthy bone mineral mass. Level of Evidence Il; Development of diagnostic criteria in consecutive patients (with applied reference "gold" standard).
\end{abstract}

Keywords: Body composition; Muscle strength; Absorptiometry, photon; Bone density; Young adult.

\section{RESUMO}

Introdução: O treinamento de força é capaz de estimular o metabolismo do tecido ósseo, aumentando o estresse mecânico sobre o sistema esquelético. No entanto, a relação direta ainda não está bem estabelecida entre as mulheres mais jovens, uma vez que deve ser descrito qual nível de aprimoramento da força é capaz de induzir mudanças efetivas na integridade óssea. Objetivos: Este estudo analisou a influência da força muscular sobre o conteúdo mineral ósseo (BMC) e a densidade mineral óssea (BMD) entre estudantes universitárias.

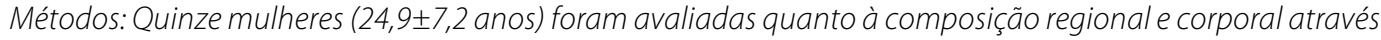
de absorciometria com raios-X de dupla energia (DEXA). Os testes de repetição máxima (1RM) foram avaliados no supino reto (SR), puxada alta (PA), flexão do joelho (FJ), extensão do joelho (EJ) e leg press $45^{\circ}$ (LP45). A regressão linear analisou as relações de BMC/BMD com a composição regional e valores dos testes $1 R M$. As medidas de dispersão e erro ( $R_{\text {aj }}^{2}$ e SEE) foram testadas definindo $p \leq 0,05$. Resultados: O valor médio do $B M C$ corporal foi de 1925,6 $\pm 240,4 \mathrm{~g}$ e BMD de 1,03 $\pm 0,07 \mathrm{~g} / \mathrm{cm}^{2}$. A massa magra (MM) foi relacionada ao BMC $\left(R_{a j}^{2}=0,86, p<0,01\right.$ e SEE $\left.=35,6 \mathrm{~g}\right)$ e à $B M D\left(R_{a j}^{2}=0,46, p<0,01, S E E=0,13 \mathrm{~g} / \mathrm{cm}^{2}\right)$ nos membros inferiores (MI). Os testes $1 R M$ no SR associaram-se com o $B M C$ e à $B M D\left(R_{a j}^{2}=0,52, p<0,01, S E E=21,4 g_{\text {, e }} R_{a j}^{2}=0,68, p<0,01\right.$, $S E E=0,05 \mathrm{~g} / \mathrm{cm}^{2}$, respectivamente) nos membros superiores, assim como os testes $1 R M$ na EJ relacionaram-se ao $B M C$ e à $B M D\left(R_{a j}^{2}=0,56, p<0,01, S E E=62,6 \mathrm{~g}\right.$, e $R_{a j}^{2}=0,58, p<0,01, S E E=0,11 \mathrm{~g} / \mathrm{cm}^{2}$, respectivamente) nos MI. Conclusões: Dessa forma, os testes $1 R M$ para exercícios multiarticulares são relevantes para o $B M C / B M D$ regional, intensificando a necessidade de incluir exercícios resistivos nas rotinas de treinamento com o propósito de melhorar a força muscular e a massa magra regional e, portanto, assegurar uma massa mineral óssea saudável. Nível de Evidência Il; Desenvolvimento de critérios diagnósticos em pacientes consecutivos (com padrão de referência "ouro" aplicado). 


\section{RESUMEN}

Introducción: El entrenamiento de fuerza es capaz de estimular el metabolismo del tejido óseo, aumentando el estrés mecánico sobre el sistema esquelético. Sin embargo, la relación directa aún no está bien establecida entre las mujeres más jóvenes, dado que debe ser descrito qué nivel de mejora de la fuerza es capaz de inducir cambios efectivos en la integridad ósea. Objetivos: Este estudio analizó la influencia de la fuerza muscular sobre el contenido mineral óseo (BMC) y la densidad mineral ósea (BMD) entre estudiantes universitarias. Métodos: Quince

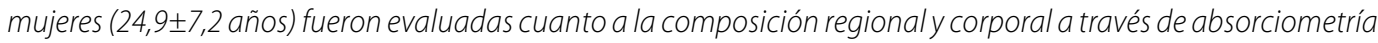
con rayos-X de doble energía (DEXA). Los tests de repetición máxima (1RM) fueron evaluados en el supino recto $(S R)$, dominada alta (DA), flexión de la rodilla (FR), extensión de la rodilla (ER) y leg press $45^{\circ}(L P 45)$. La regresión lineal analizó las relaciones de BMC/BMD con la composición regional y valores de los tests $1 R M$. Las medidas de dispersión y error ( $R_{a j}^{2}$ y SEE) fueron probadas definiendo $p \leq 0,05$. Resultados: El valor promedio del $B M C$ corporal fue de 1925,6 $\pm 240,4 \mathrm{~g}$ y $B M D$ de $1,03 \pm 0,07 \mathrm{~g} / \mathrm{cm}^{2}$. La masa magra $(M M)$ fue relacionada al $B M C\left(R_{a j}^{2}=0,86\right.$, $p<0,01$ y $S E E=35,6 \mathrm{~g})$ y a la $B M D\left(R_{a j}^{2}=0,46, p<0,01, S E E=0,13 \mathrm{~g} / \mathrm{cm}^{2}\right)$ en los miembros inferiores (MI). Los tests $1 R M$ en el SR se asociaron con el BMC y a la BMD $\left(R_{a j}^{2}=0,52, p<0,01, S E E=21,4 \mathrm{~g}\right.$, y $R_{a j}^{2}=0,68, p<0,01$, SEE $=0,05 \mathrm{~g} / \mathrm{cm}^{2}$, respectivamente) en los miembros superiores, asi como los testes $1 R M$ en la ER se relacionaron al $B M C$ y a la BMD $\left(R_{a j}^{2}=0,56, p<0,01, S E E=62,6 \mathrm{~g}, y R_{a j}^{2}=0,58, p<0,01, S E E=0,11 \mathrm{~g} / \mathrm{cm}^{2}\right.$, respectivamente) en los MI. Conclusiones: De esa forma, los tests $1 R M$ para ejercicios multiarticulares son relevantes para el BMC/BMD regional, intensificando la necesidad de incluir ejercicios resistivos en las rutinas de entrenamiento con el propósito de mejorar la fuerza musculary la masa magra regional y, por lo tanto, asegurar una masa mineral ósea saludable. Nivel de Evidencia II; Desarrollo de criterios diagnósticos en pacientes consecutivos (con estándar de referencia "oro" aplicado).

Descriptores: Composición corporal; Fuerza muscular; Absorciometría de fotón; Densidad ósea; Adulto joven.

\section{INTRODUCTION}

Osteoporosis is a public health problem that affects millions of people around the world. ${ }^{1}$ It is estimated that the number of osteoporotic fractures doubles in the next 50 years, influencing the increase in morbidity and mortality of the population. The main way to reduce the osteoporosis risk is prevention. The physical activity level, diet, lifestyle and genetic factors interfere with bone mineral density and content (BMD and BMC) and, consequently, the propensity to disease. Thus, it can be established that the practice of regular physical activity when initiated during childhood and adolescence would be a prevention strategy against the reduction of BMD and BMC and, thus, retarding skeletal aging., ${ }^{2,3}$

It has been observed that BMD reduction is positively associated with age, evidencing rates of $0.6 \%, 1.1 \%$ and $2.1 \%$ of loss, respectively, for the age groups between $60-69,70-79$ and $\geq 80$ years. ${ }^{4}$ These changes often culminate with osteoporosis, but tend to be minimized by regular physical activity and maintenance of body fat and lean mass. ${ }^{4-6}$ When analyzing the association between aging, decline in physical activity and reductions BMC and lean mass (LM), Proctor et al.7 observed that between 20 and 80 years of age there is a tendency of reduction in physical activity between 34-38\% for women and men, while reduction in LM (18-17\%) and BMC (16-30\%). These same authors also showed high and significant correlations between LM and BMC for males ( $r=0.77$ ) and females $(r=0.74)$. Lee et al. ${ }^{8}$ study corroborated this association, concluding that $L M$ is a significant and independent determinant of total and regional bone mineral mass, presenting low coefficients $\left(R^{2}<0.5\right)$ but significant $(p<0.01)$. For associations between appendicular mass (Kg) and total, pelvic and forearm BMD. These associations between body composition and bone mineral mass were also observed by Makovey et al. ${ }^{6}$ in populations of both sexes in different age groups. According to the results of these authors, both LM and fat mass (FM) positively influence BMC, with explanatory power of $52 \%$ for the variances between LM and BMC and of $20 \%$ between FM and BMC. The explanations for these associations are the integrity of the neuromuscular system as a mechanical regulating factor of osteogenic activity, and the influence of fat on estrogen secretion as a humoral factor in the regulation of osteoblast activity. ${ }^{6,8}$

In turn, strength training presents well-known prescriptions in BMD regulation, and it is recommended to perform exercises with high loads, including 2-3 sets per exercise performed 3 times per week in a 4-6 month planning. ${ }^{9-11}$ Long-term training protocols (> 12 months), with load intensity between $50-80 \%$ of a maximal repetition (1RM) involving upper limbs (UL) and lower limbs (LL) increased BMD by up to 3.8\% or prevented significant reductions ( $2.5 \%$ ) when compared to the control group. ${ }^{9-12}$ Collectively, the results suggest that protocols including prescriptions of high load intensity (12 to 15 RMs or 70-80\% 1RM).

The relationship between muscle strength and $B M C$ and $B M D$ is assumed by the influence of mechanical stress on the metabolism of bone tissue, however, it is assumed that among young individuals with intact bone health, the increased strength does not play a decisive role in distinguishing more or less healthy skeletal structures. However, once the relationship between strength and lean mass (regional and/ or whole-body) is assumed, a possible relationship between strength and $\mathrm{BMC}$ or BMD can also be assumed, assuming that the relationship between whole-body lean mass and BMC or BMD is well established. The aim of the present study was to analyze the influence of muscle strength aptitude on bone health parameters (BMD and BMC) among university students in search of relationships that establish a regional or whole-body causal effect that can be mutually indexed the healthy state, or propensity for future risks.

\section{MATERIALS AND METHODS}

The sample consisted of 15 women, with the following characteristics: $24.9 \pm 7.2$ years of age, $162.4 \pm 5.0 \mathrm{~cm}$ in height and $59.1 \pm 6.2 \mathrm{~kg}$ of body weight. This research was submitted to the Local Ethics Committee of the University (CAEE: 70076317.1.0000.5398). The procedures were explained to the participants and they signed the Informed Consent Form (ICF) that authorized their participation in the process. 
The DXA method (Hologic model, QDR Discovery Wi ) was used to obtain the regional and whole-body composition. The body composition software (Hologic APEX) presented values of fat mass (FM) and fat-free mass (lean mass and bone mineral), in grams, for upper and lower limbs on both body sides, which together provided the references of regional composition (fat mass, fat-free mass and total mass) of upper and lower limbs, trunk and whole-body. The equipment was calibrated following the manufacturer's recommendations and all analyses were performed by an experienced technician. Participants presented for evaluation with light clothing, without shoes and any metallic object attached to the body and clothes; and were instructed to remain in the supine position on the flat table until the end of the checking. Their feet remained close together and their arms were placed parallel to the trunk. The lines were adjusted by the same technician through specific anatomical points determined by the manufacturer.

1RM tests were performed on the following devices: (a) horizontal bench press (BP), (b) lat-pull down (LPD), (c) knee extension (KE), (d) leg-curl (LC), and (e) leg press $45^{\circ}$ (LP45). All tests were performed after a 15-minute warm-up (static stretching, cycling or running at low intensity). The 1 RM test protocol followed the recommendations of Mayhew et al. ${ }^{13}$ and Baechle and Earle": (1) A specific warm-up precedes the test, with repetitions performed at light intensity load avoiding concentric failure; (2) Initial loads were established based on mean maximum strength rates of lower and upper limbs, according to age, sex and weight; (3) the participants performed at least three attempts with 3 min resting between each, increasing or decreasing the initial lifted load from 1.1 to $4.5 \mathrm{~kg}$, according to level difficulty of the first attempt. The highest weight successfully raised once represented the 1RM reference value. The value of the load was shown in kilograms $(\mathrm{kg})$. The 1RM test was performed three times for the analysis of reliability. For each second and third repetition, the value of 1 RM obtained from first repetition was fractioned into five percentages (90, 95, 100, 105 and 110\%) and performed in a random manner with 3 minutes of rest between each following attempt to found maximal load able to be lift once. Participants were also instructed to perform the movements with the appropriate technique, following the recommendations of the NSCA. ${ }^{14}$

\section{Estatistical analysis}

Variables were evaluated around the mean \pm standard deviation and minimum and maximum values. Normality was verified by the Shapiro Wilk test. Linear regression, using the Stepwise method, modeled the relationship between the observed BMD and BMC values (as dependent factors) with the anthropometric variables, regional and whole-body composition, and upper (BP, LPD) and lower limb strength (KE, LC, LP45) (as independent factors). Dispersion and variability measurements were tested by the coefficient of variance adjusted to the sample $\left(R_{\text {adj }}^{2}\right)$ between dependent and independent variables. All statistical procedures were performed in SPSS 19 (Statistical Package for Social Sciences, Inc., USA), with a level of significance of $p \leq 0.05$.

The sample power for the associations between dependent and independent variables was determined considering the sample size (Women $=15$ ). The entry parameters were: (a) the coefficient " $r$ ", from the analysis of variance $\left(R^{2}\right)$, (b) $Z \alpha=1.96$ for an index of $\alpha=0.05$, and safety (c) $Z_{1-\beta}=1.282$ for a sample with a minimum power of $80 \%$ $(\beta=0.20)$, according to Diaz and Fernandez: ${ }^{15}$

$$
Z_{1-\beta}=\sqrt{n-3} \frac{1}{2} \ln \left(\frac{1+r}{1-r}\right)-Z_{1-\alpha / 2}
$$

In addition to the sampling power, magnitude-based inference analysis was applied to test the chances of the true magnitude of an effect to be substantially positive and negative, and negligible or trivial (with a probability of 66 to ensure a decisively useful effect: benefits $>25 \%$ and $<0.5 \%$ chance of losses). The odds were assessed qualitatively, from borderline values according to the scale: $<1 \%=$ most unlikely; $1 \%-5 \%$ = very unlikely; $5 \%-25 \%=$ unlikely; $25 \%-75 \%=$ possibly $; 75 \%-95 \%=$ likely; $95 \%-99.5 \%=$ very likely; and $>100 \%=$ most likely. This procedure ensures that the sampling distribution of $z=[0.5 \times \ln \times((1+r) /(1-r))]$ will tend approximately to normality with variance $1 /(n-3){ }^{16}$

\section{RESULTS}

The observed values of BMC and BMD for regional and whole-body are presented in Table 1. These values produced corporal scales $(=-0.98)$, which classify BMD as normal, that is, in the reference range for young adults of both genders ( $T \geq-1$ standard deviation). The percentage of whole-body FM was $32.7 \pm 6.6 \%$, classifying body adiposity as overweight. Table 2 presents the values for the Pearson coefficients observed between regional and whole-body lean mass with BMC and BMD. Only whole-body lean mass $(37.52 \pm 2.71 \mathrm{~kg})$ was found to be associated with all BMC and BMD values (except for whole-body and upper limb $\mathrm{BMD})$. The other values of lean mass were: $3.60 \pm 0.52 \mathrm{~kg}(\mathrm{UL}), 17.94 \pm$ $1.2 \mathrm{~kg}(\mathrm{~T})$, and $12.90 \pm 1.27 \mathrm{~kg}(\mathrm{LL})$. These values were correlated with $B M C$ values (except for the lumbar vertebrae), but only BMD of the lower limbs is related to lean mass values.

The potential for determination between lean mass parameters and $B M C$ and BMD values is shown in Figure 1. It is noted that whole-body lean

Table 1. Mean values $\pm S D$ for $B M C$ and $B M D$ regional and body of the participants. $\mathrm{N}=15$.

\begin{tabular}{c|c|c|c}
\hline & & Mean \pm SD & Range \\
\hline \multirow{4}{*}{ BMC (g) } & Trunk & $502.5 \pm 87.4$ & $315.2-619.8 \mathrm{~g}$ \\
\cline { 2 - 4 } & Upper limb & $239.2 \pm 31.1$ & $189.4-295.2 \mathrm{~g}$ \\
\cline { 2 - 4 } & Lower limb & $663.7 \pm 94.3$ & $501.3-795.3 \mathrm{~g}$ \\
\cline { 2 - 4 } & Thoracic V. & $95.9 \pm 17.2$ & $57.3-113.5 \mathrm{~g}$ \\
\cline { 2 - 4 } & Lumbar V. & $52.1 \pm 12.8$ & $26.2-69.5 \mathrm{~g}$ \\
\cline { 2 - 4 } & Pelvis & $198.1 \pm 51.5$ & $113.6-278.0 \mathrm{~g}$ \\
\cline { 2 - 4 } & Whole-body & $1925.6 \pm 240.4$ & $1359.6-2248.4 \mathrm{~g}$ \\
\hline & Trunk & $4.2 \pm 0.38$ & $3.34-4.75 \mathrm{~g} / \mathrm{cm}^{2}$ \\
\cline { 2 - 4 } & Upper limb & $1.32 \pm 0.97$ & $1.15-1.53 \mathrm{~g} / \mathrm{cm}^{2}$ \\
\cline { 2 - 4 } & Lower limb & $2.05 \pm 0.17$ & $1.7-2.38 \mathrm{~g} / \mathrm{cm}^{2}$ \\
\cline { 2 - 4 } & Thoracic V. & $0.78 \pm 0.08$ & $0.56-0.87 \mathrm{~g} / \mathrm{cm}^{2}$ \\
\cline { 2 - 4 } & Lumbar V. & $1.10 \pm 0.13$ & $0.82-1.25 \mathrm{~g} / \mathrm{cm}^{2}$ \\
\cline { 2 - 4 } & Pelvis & $1.10 \pm 0.10$ & $0.91-1.29 \mathrm{~g} / \mathrm{cm}^{2}$ \\
\cline { 2 - 4 } & Whole-body & $1.03 \pm 0.07$ & $0.85-1.17 \mathrm{~g} / \mathrm{cm}^{2}$ \\
\hline
\end{tabular}

Table 2. Pearson's coefficients between regional and body mass values and BMC / BMD for body and body segments. $\mathrm{N}=15$.

\begin{tabular}{c|c|c|c|c|c}
\hline & & \multicolumn{4}{|c}{ Lean Mass (g) } \\
\hline & & Whole-body & Trunk & Upper Limb & Lower Limb \\
\hline \multirow{5}{*}{ BMC (g) } & Whole-body & $0.757^{* *}$ & $\mathrm{~ns}$ & $0.630^{*}$ & $0.639^{*}$ \\
\cline { 2 - 6 } & Thoracic V. & $0.779^{* *}$ & $0.532^{*}$ & $0.762^{* *}$ & $0.757^{* *}$ \\
\cline { 2 - 6 } & Lumbar V. & $0.547^{*}$ & $\mathrm{~ns}$ & $\mathrm{~ns}$ & $\mathrm{Ns}$ \\
\cline { 2 - 6 } & Pelvis & $0.697^{*}$ & $0.572^{*}$ & $0.598^{*}$ & $0.606^{*}$ \\
\cline { 2 - 6 } & Trunk & $0.757^{* *}$ & 0.500 & $0.647^{* *}$ & $0.642^{*}$ \\
\cline { 2 - 6 } & Upper Limb & $0.554^{*}$ & $\mathrm{~ns}$ & $0.569^{*}$ & $0.530^{*}$ \\
\cline { 2 - 6 } & Lower Limb & $0.931^{* *}$ & $0.728^{* *}$ & $0.878^{* *}$ & $0.871^{* *}$ \\
\hline \multirow{5}{*}{ BMD (g/cm $\left.{ }^{2}\right)$} & Pelvis & $0.525^{*}$ & $\mathrm{~ns}$ & $\mathrm{~ns}$ & $\mathrm{~ns}$ \\
\cline { 2 - 6 } & Whole-body & $\mathrm{ns}$ & $\mathrm{ns}$ & $\mathrm{ns}$ & $\mathrm{ns}$ \\
\cline { 2 - 6 } & Thoracic V. & $0.525^{*}$ & $\mathrm{~ns}$ & $\mathrm{~ns}$ & $\mathrm{Ns}$ \\
\cline { 2 - 6 } & Lumbar V. & $0.521^{*}$ & $\mathrm{~ns}$ & $\mathrm{~ns}$ & $0.541^{*}$ \\
\cline { 2 - 6 } & Upper Limb & $0.529^{*}$ & $\mathrm{~ns}$ & $\mathrm{~ns}$ & $\mathrm{Ns}$ \\
\cline { 2 - 6 } & Lower Limb & $0.528^{*}$ & $0.651^{* *}$ & $0.667^{* *}$ & $0.621^{*}$ \\
\hline
\end{tabular}

Note: significant correlation at ${ }^{*} \mathrm{p} \leq 0.05$ and ${ }^{* *} \mathrm{p} \leq 0.01$. The abbreviation "ns" refers to a non-significant correlation to the stipulated levels. 
mass presents greater potential than regional values in determining BMC and $\mathrm{BMD}$ regional or whole-body. Whole-body lean mass determined BMC of lower limbs (Figure 1, Panel A) with $\mathrm{R}_{\text {adj }}(=0.87, \mathrm{p}<0.01)$, SEE (=35.6 grams) and sample power (=99.9\%), whose effect was considered "quite likely to be substantially positive"; and the association with BMD of lower limbs (Figure 1, Panel B) presented $\mathrm{R}_{\text {adj }}^{2}(=0.52, \mathrm{p}<0.01)$, SEE $\left(=0.13 \mathrm{grams} / \mathrm{cm}^{2}\right)$ and sample power $(=77.0 \%)$, whose effect can also be considered "quite likely to be substantially positive".

The strength values in the 1RM test for the bench press $(29.6 \pm 5.5 \mathrm{~kg})$, lat-pull down $(32.2 \pm 5.1 \mathrm{~kg})$, leg-curl $(42.3 \pm 10.4 \mathrm{~kg})$, knee extension $(65.3 \pm 19.6 \mathrm{~kg})$ and leg press $45^{\circ}(187.6 \pm 57.5 \mathrm{~kg})$ correlated with regional $\mathrm{BMC}$ and $\mathrm{BMD}$ values for lower limbs (Table 3). Table 3 also shows that strength values are related to BMC/BMD regional values of the lower limbs, except for the force in the knee flexion exercises. This is also the case when observing strength correlations with whole-body BMC values. It should be noted that the force in the knee extension

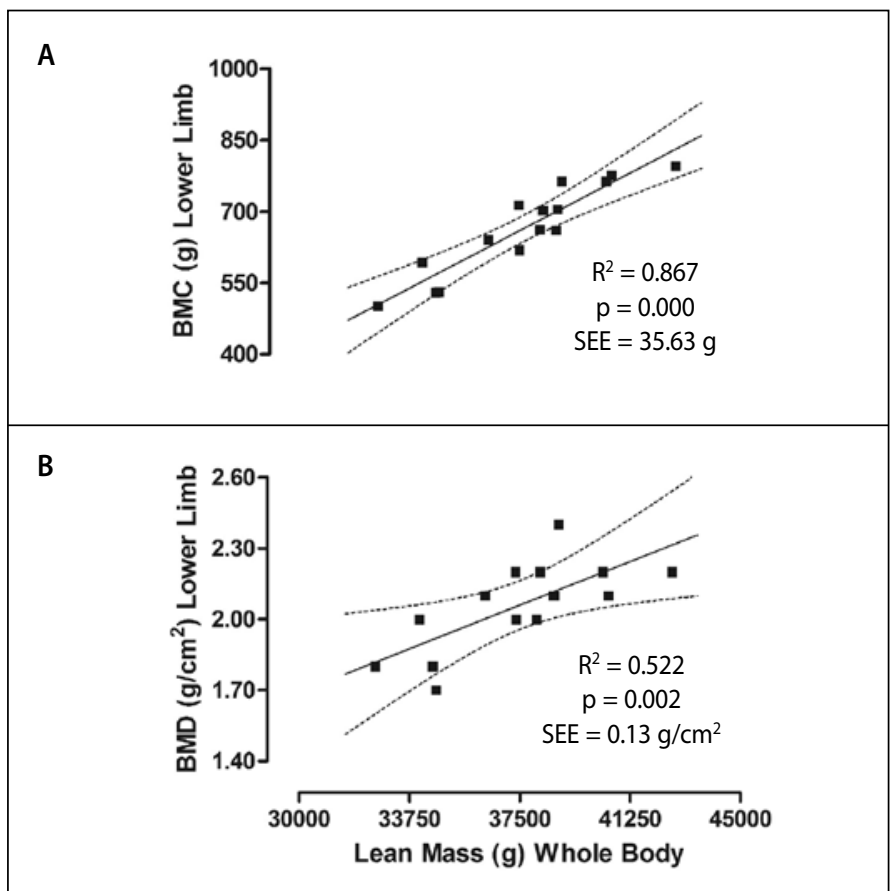

Figure 1. Regression analysis between whole-body lean mass and BMC (Panel A) and BMD (Panel B) indices for lower limbs. $\mathrm{N}=15$.

Table 3. Pearson's coefficient between muscle strength values and regional and body BMC / BMD. $\mathrm{N}=15$.

\begin{tabular}{|c|c|c|c|c|c|c|}
\hline & & \multicolumn{4}{|c|}{ Strenght teste 1RM (kg) } & \multirow[b]{2}{*}{$\begin{array}{c}\text { Leg } \\
\text { Press } 45^{\circ} \\
\end{array}$} \\
\hline & & $\begin{array}{l}\text { Bench } \\
\text { Press }\end{array}$ & \begin{tabular}{|l|} 
Front \\
Pulley \\
\end{tabular} & $\begin{array}{c}\text { Flexion } \\
\text { Knee }\end{array}$ & \begin{tabular}{|c}
$\begin{array}{c}\text { Extension } \\
\text { Knee }\end{array}$ \\
\end{tabular} & \\
\hline \multirow{7}{*}{$\mathrm{BMC}(\mathrm{g})$} & Whole-body & $0.673^{* *}$ & $0.549^{*}$ & ns & $0.697^{* *}$ & $0.628^{* *}$ \\
\hline & Thoracic V. & $0.678^{* *}$ & $0.743^{* *}$ & $0.573^{*}$ & $0.713^{* *}$ & $0.852^{* *}$ \\
\hline & Lumbar V. & Ns & Ns & ns & Ns & Ns \\
\hline & Pelvis & Ns & Ns & $0.553^{*}$ & $0.584^{*}$ & Ns \\
\hline & Trunk & $0.519^{*}$ & 0.476 & $0.515^{*}$ & $0.667^{* *}$ & $0.636^{*}$ \\
\hline & Upper Limb & $0.747^{* *}$ & $0.730^{* *}$ & ns & $0.637^{*}$ & $0.570^{*}$ \\
\hline & Lower Limb & $0.526^{*}$ & $0.723^{* *}$ & $0.705^{* *}$ & $0.769^{* *}$ & $0.714^{* *}$ \\
\hline \multirow{7}{*}{$\mathrm{BMD}\left(\mathrm{g} / \mathrm{cm}^{2}\right)$} & Whole-body & $0.655^{* *}$ & Ns & ns & $0.583^{*}$ & ns \\
\hline & Thoracic V. & $0.616^{*}$ & Ns & ns & $0.533^{*}$ & $0.573^{*}$ \\
\hline & Lumbar V. & $0.628^{*}$ & Ns & ns & $0.603^{*}$ & $0.710^{* *}$ \\
\hline & Pelvis & Ns & Ns & $0.560^{*}$ & $0.609^{*}$ & ns \\
\hline & Trunk & $0.588^{*}$ & Ns & ns & $0.620^{*}$ & $0.595^{*}$ \\
\hline & Upper Limb & $0.840^{* *}$ & $0.551^{*}$ & ns & $0.654^{* *}$ & $0.641^{* *}$ \\
\hline & Lower Limb & $0.602^{*}$ & $0.550^{*}$ & $0.660^{* *}$ & $0.781^{* *}$ & $0.669^{* *}$ \\
\hline
\end{tabular}

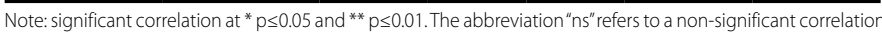
to the stipulated levels. exercise correlates with all BMC/BMD regional and whole-body values, except for the lumbar vertebrae. The bench press exercise also stands out, presenting correlations with BMC/BMD regional and whole-body values, with the exception of Pelvis.

Figure 2 illustrates the potential of the association between muscle strength in upper and lower limb exercises and BMC/BMD. In upper limbs, the bench press (exercises that reflect the maximum capacity of force in the push action) was associated to the BMC (Panel A) with $\mathrm{R}_{\text {adj }}(=0.56, \mathrm{p}<0.01)$, $\mathrm{SEE}(=21.4$ grams) and sample power $(=83.4 \%)$, whose effect was considered "very likely to be substantially positive". Indeed, the association between bench press and BMD (Panel B) also is presented, with $R_{\text {adj }}^{2}(=0.71, p<0.01)$, SEE $\left(=0.05 \mathrm{grams} / \mathrm{cm}^{2}\right)$ and sample power (=97.8\%), showing effect "very likely to be substantially positive". For the lower limbs, the strength in the knee extension exercise (exercise representative of the maximum capacity of the traction force of the legs) was associated to both BMC (Panel $C$ : $R^{2}$ adj $=0.59, p<0.01$, $\mathrm{SEE}=62.6$ grams and sample power $=88.2 \%)$ and $\mathrm{BMD}\left(\right.$ Panel $\mathrm{D}: \mathrm{R}_{\text {adj }}=$ $0.63, \mathrm{p}<0.01$, SEE $=0.11 \mathrm{grams} / \mathrm{cm}^{2}$ and sample power $=92.8 \%$ ), with effect "very likely to be substantially positive".

\section{DISCUSSION}

The results demonstrated that variations in BMC and BMD, among young women, are associated with both upper and lower limb strength and whole-body lean mass. These results are consistent with the fact that lean mass and bone mineral variables are strongly related regardless of gender and age, especially among women younger than 50 years. ${ }^{6}$ However, the results showed that muscle strength also correlates with BMC/BMD in similar magnitude order (or only slightly lower) to the association that the lean body mass parameter presented with BMC/ BMD. This tendency of association between BMC/BMD strength has been little evidenced, although muscle strength is consistently reported as indicative of muscle mass and functional quality among people of any gender and age. ${ }^{4}$ This means that the interaction between strength and muscle mass ensures that it is inserted in contexts that stimulate the osteogenic process, caused by the mechanical stress of the different types of physical activities, mainly the exercise with weights, as well as the lower propensity to accumulate fat. $4,7,8,17,18$

On the one hand, the whole-body lean mass presents well documented evidence of association with $\mathrm{BMC} / \mathrm{BMD}^{6,7}$ which in part can be explained by the fact that BMC/BMD decline more sharply with the advancement of the age among women when compared to men, and is also accompanied by a decline in lean mass and level of physical activity. In the study by Proctor et al., ${ }^{7}$ this decline was quantified. For these authors, BMC/BMD declines 30\% between 20 and 80 years in women, since the reduction of lean mass is $18 \%$ and physical activity is $34 \%$ among women. That is, women do not tend to maintain stable the ratio between lean mass and mineral mass in the fat-free mass composition, when compared to men, whose trend had already been described by Horber et al.. ${ }^{17}$ However, it is noted that the mobility and vitality of men are more susceptible to reductions of BMC/BMD and lean mass, although smaller, when compared to the women in the maintenance of the levels of physical activity. This evidence corroborated the findings of Horber et al. ${ }^{17}$ who observed a gender specificity in how body composition and muscle metabolism change with age. These authors pointed out that the loss of lean mass among women is associated with the accumulation of fat in the upper limbs. This trend assists in understanding the impact of upper limb lean mass reduction on physical fitness, but also suggests the importance of regional analysis of morphological and functional characteristics, since these may be tied to preferences for engaging in specific exercises for a particular body region. ${ }^{19}$ 


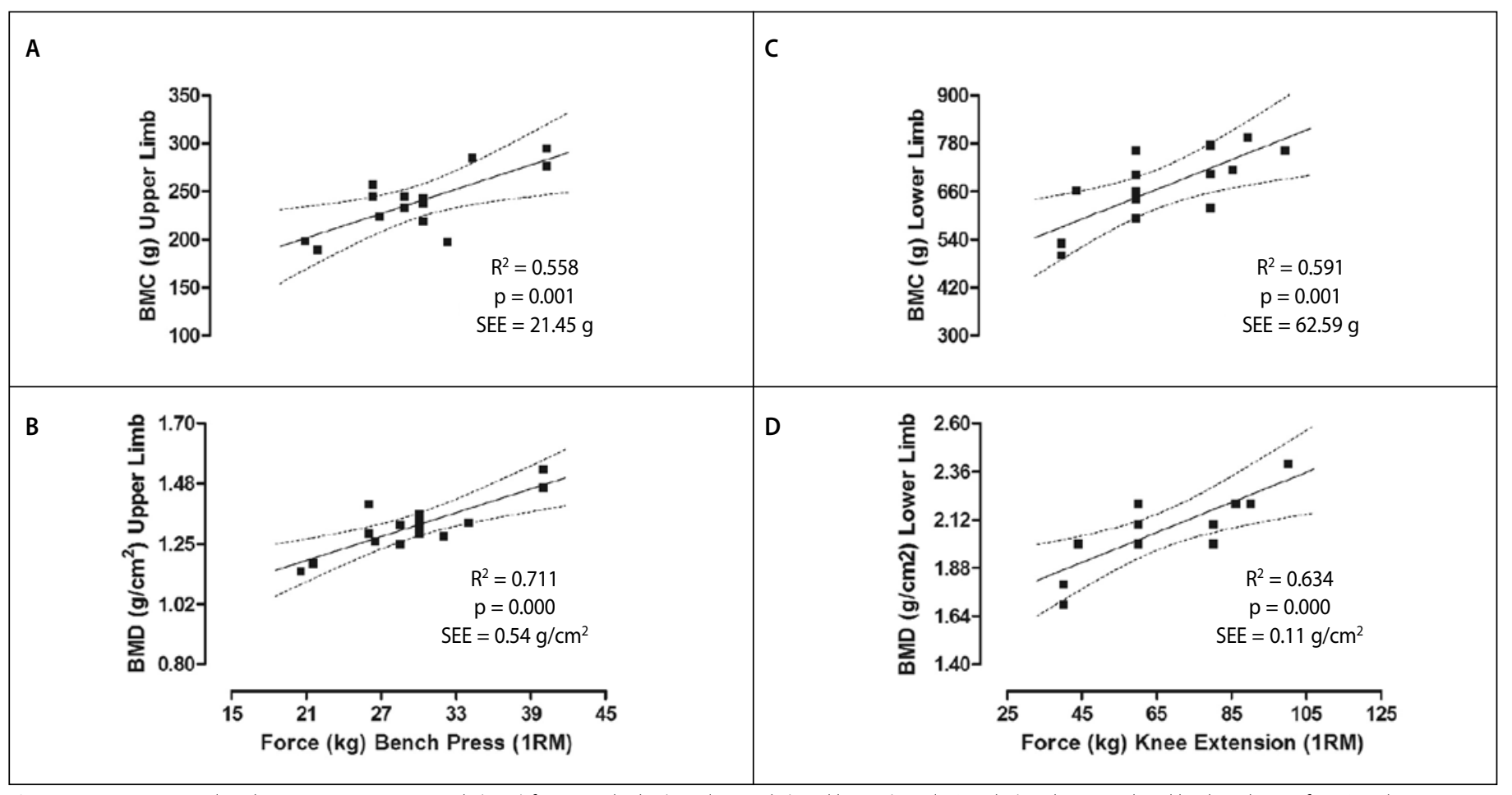

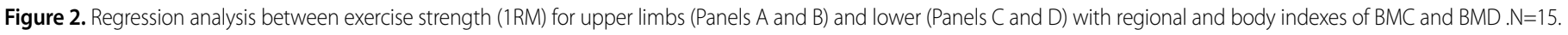

However, the regional body lean mass is still timidly investigated, ${ }^{12,18,19}$ perhaps due to the fact that the experimental designs involved specific measures of BMD/BMC (hip and spine) and to approach elderly participants with diagnosis of bone mineral integrity disorders (osteopenia and osteoporosis). $7,18,19$ Thus, the present study confirms the expectation of the positive association between body lean mass and BMC/BMD regional and whole-body, adding the occurrence of a local tendency that makes the specific association between variables of the same body location. Then, if some studies are emphatic in assuming a dubious posture about which body composition parameter (lean mass, fat mass or both) influences the integrity of the bone mineral mass among women and with advancing age ${ }_{1}^{6}$ the results presented in this study reinforce that whole-body lean mass tends to ratify the regional composition as an independent factor of bone mineral integrity.

In the present study, the assessment of maximum strength in weight exercises also presented as a tool with practical potential to indicate variations in BMC/BMD, both regional and whole-body, among young women. On the other hand, the information available in the literature indicates that the force exerts greater influence on BMC/BMD than regional lean mass (legs or arms) or whole-body mass. ${ }^{20}$ On the other hand, there are also results contrary to this perspective, indicating that the increase of muscle strength is not related to the increase of muscle mass, nor is the muscular strength presentes potential to parameterize the variations in BMC/BMD. ${ }^{21}$ In this way, the results of the present study contribute to point out the muscle strength in exercises with weights as a promising index of the lean mass and its functional capacity and, in particular, its role in monitoring variations in bone mineral integrity.

As for muscle strength, it is worth mentioning the presented association by the force in bench press and knee extension (both exercises that represent the involvement of the large muscle groups, respectively of the upper and lower limbs), ${ }^{22}$ which were related to BMC/BMD of the respective body regions (upper and lower limb). Despite modest predictive potential, and no higher than presented by whole-body lean mass, this association is due to the assumption that the bench press and knee flexion are considered exercises that involving large muscle mass in the execution, ${ }^{22}$ and therefore have both local and global influence, since they also showed correlations with whole-body BMC/BMD. These results are in accordance with presented data by Hughes et al. ${ }^{23}$ on the absence of association between muscle strength in single-joint exercises and bone mineral density, which was related to whole-body lean mass. However, the present results fully corroborate the observation of Lee et al. ${ }^{8}$ who concluded on the importance of the muscle strength development reduce the osteoporosis risk, after having verified the occurrence of a relationship between whole-body lean mass and bone mass of the hip (region with the highest levels of osteopenia). In our results, the regional pelvic BMC/BMD (which included the pelvic girdle, neck and head femoral) also showed significant associations with strength of the lower limb in single-joint exercises (knee extension) for females. It should also be noted that these relationships were presented with trunk BMC/BMD, which included other sites equally important for the osteoprosis diagnosis, such as the thoracic and lumbar vertebrae. ${ }^{24}$ However, these correlations were not higher than those presented between whole-body lean mass with BMC of pelvis, but curiously, only the whole-body lean mass associated with BMD of pelvis among women. This way, the results of the present study allow to extend the findings by Lee et al. ${ }^{8}$, defining the strength in global and local exercises as an equally important index to whole-body lean mass in the osteoprosis prevention on the pelvic and trunk bone sites.

However, our results did not cover specific sites (hip and lower spine) when assessing densitometry and establishing relationships of the strenght with regional and whole-body composition. In addition, the fat mass reassay for BMC/BMD was not considered, since among women, regional and whole-body fat tend to exert a protective effect on hip BMD, presumably because of its role in the regulation of estrogen secretion and effect of this humoral factor on the osteoblastos activity. $6,25,26$ However, among women, the upper body fat accumulation occurs due to aging and sedentary lifestyle, especially after 50 years, causing bone and skeletal muscle mass reduction. ${ }^{10,15,27,28}$ These are present study limitations of the because the analysis of specific sites would make the potential of the results more elucidative in the clinical field, whereas a possible correlation between BMC/BMD and fat mass (regional or whole-body) could reduce the deterministic potential of lean mass, which was observed in the present study for young women. 


\section{CONCLUSION}

In the present study, the results confirmed the whole-body lean mass as an influential factor on bone mineral integrity; and suggested that the muscle strength capacity is also a determinant of regional and whole-body BMC/BMD. Thus, the muscular strength development is repeatedly important for maintaining function of whole-body lean mass in young people, and positively affecting bone mass, given either directly or indirectly by its relation between regional and whole-body lean mass. It is recommended, therefore, that resistance exercise be part of the youth training plan as a prophylactic measure and that the prescription plan involves the regional lean mass of lower and upper limbs. In addition, it is recommended that training aim at reducing body-fat accumulation and ensuring functional independence, since the lean mass increase in relative or absolute terms is a predictor of relevance extreme. By this bias, future studies should explore whether the caloric cost of different training routines (resistance, cardiorespiratory resistance and/or combinations thereof) would be a more conclusive parameter to define the exercise intensity that would be most effective in the morphological changes of lean tissue. As well as, it is recommended that future studies explore analyzes of specific body sites and of a high incidence of osteoporosis.

All authors declare no potential conflict of interest related to this article.

AUTHORS' CONTRIBUTIONS: Each author made significant individual contributions to this manuscript. DMPF (0000-0003-3975-9260)*, LOCS (0000-0003-0585-4593)*, DS $(0000-0002-5565-2351)^{*}$, BRG (0000-0003-3058-998X)* and CMN (0000-0003-1635-3209)*: were responsible for the conception of the proposal, data collection, presentation of results and literary discussion of the results observed. ARS (0000-0003-0653-5383)*, LGAS (0000-0002-4589-2933)*, LDP (0000-0001-7956-894X)* and DAM (0000-00031088-0040)* monitored data processing and contributed to the revision of the manuscript and conceptual basis of the study, as well as that of the final conceptual review. All authors contributed to the intellectual concept of the study and approved the final version of the manuscript. *ORCID (Open Researcher and Contributor ID).

\section{REFERENCES}

1. Kai MC, Anderson M, Lau EM. Exercise interventions: defusing the world's osteoporosis time bomb. Bull World Health Organ. 2003;81(11):827-30.

2. Hall SJ. Biomecânica básica. 4.ed. Rio de Janeiro: Guanabara Koogan, 2005.

3. Spirduso WW. Dimensões físicas do envelhecimento. São Paulo: Manole, 2005.

4. Gomez-Cabello A, Ara I, González-Agüero A, Casajus JA, Vicente-Rodríguez G. Effects of training on bone mass in older adults: a systematic review. Sports Med. 2012;42(4):301-25.

5. Ackland TR, Lohman TG, Sundgot-Borgen J, Maughan RJ, Meyer NL, Stewart AD, et al. Current status of body composition assessment in sport. Sports Med. 2012;42(3):227-49.

6. Makovey J, Naganathan V, Sambrook P. Gender differences in relationships between body composition components, their distribution and bone mineral density: a cross-sectional opposite sex twin study. Osteoporos Int. 2005;16(12);1495-505.

7. Proctor DN, Melton L, Khosla S, Crowson CS, O'Connor MK, Riggs BL. Relative influence of physical activity, muscle mass and strength on bone density. Osteoporos Int. 2000;11(11):944-52.

8. Lee N, Radford-Smith GL, Forwood M, Wong J, Taaffe DR. Body composition and muscle strength as predictors of bone mineral density in Crohn's disease. J Bone Miner Metab. 2009;27(4):456-63.

9. Nelson ME, Fiatarone MA, Morganti CM, Trice I, Greenberg RA, Evans WJ. Effects of high-intensity strength training on multiple risk factors for osteoporotic fractures: a randomized controlled trial. JAMA. 1994;272(24):1909-14.

10. Bocalini DS, Serra AJ, dos Santos L, Murad N, Levy RF. Strength training preserves the bone mineral density of postmenopausal women without hormone replacement therapy. J Aging Health. 2009;21 (3):519-27.

11. de Matos O, Lopes da Silva DJ, Martinez de Oliveira J, Castelo-Branco C. Effect of specific exercise training on bone mineral density in women with postmenopausal osteopenia or osteoporosis. Gynecol Endocrinol. 2009:25(9):616-20.

12. Menkes A, Mazel S, Redmond RA, Koffler K, Libanati CR, Gundberg CM, et al. Strength training increases regional bone mineral density and bone remodeling in middle-aged and older men. J Appl Physiol. 1993;74(5):2478-84.

13. Mayhew JL, Clemens CT, Busby JC, Cannon KL, Ware JS, Bowen JC. Cross-validation of equations to predict 1-RM bench press from repetitions-to-failure:1170. Med Sci Sports Exerc. 1995;27(5):S209.

14. Baechle TR, Earle RW. Essentials of strength training and conditioning/National Strength and Conditioning Association. $3^{\text {rd }}$.ed. Champaign: Human Kinetics, 2008
15. Díaz SP, Fernández SP. Determinación del tamaño muestral para calcular la significación del coeficiente de correlación lineal. Cad Aten Primaria. 2002;9:209-11.

16. Hopkins WG, Marshall SW, Batterham AM, Hanin J. Progressive statistics for studies in sports medicine and exercise science. Med Sci Sports Exerc. 2009;41(1):3-12.

17. Horber FF, Gruber B, Thomi F, Jensen EX, Jaeger P. Effect of sex and age on bone mass, body composition and fuel metabolism in humans. Nutrition. 1997;13(6):524-34.

18. Goodpaster BH, Park SW, Harris TB, Kritchevsky SB, Nevitt M, Schwartz AV. The loss of skeletal muscle strength, mass, and quality in older adults: the health, aging and body composition study. J Gerontol A Biol Sci Med Sci. 2006;61(10):1059-64.

19. Taaffe DR, Cauley JA, Danielson M, Nevitt MC, Lang TF, Bauer DC, et al. Race and sex effects on the association between muscle strength, soft tissue, and bone mineral density in healthy elders: the health, aging, and body composition study. J Bone Miner Res. 2001;16(7):1343-52.

20. Frontera WR, Meredith CN, O'Reilly KP, Knuttgen HG, Evans WJ. Strength conditioning in older men: skeletal muscle hypertrophy and improved function. J Appl Physiol. 1988;64(3):1038-44.

21. Vincent KR, Braith RW. Resistance exercise and bone turnover in elderly men and women. Med Sci Sports Exerc. 2002;34(1):17-23.

22. Heyward VH. Advanced fitness assessment \& exercise prescription. 3rd.ed. Champaign: Human Kinetics, 1997.

23. Hughes VA, Frontera WR, Dallal GE, Lutz KJ, Fisher EC, Evans WJ. Muscle strength and body composition: associations with bone density in older subjects. Med Sci Sports Exer. 1995;27(7):967-74.

24. Johnell O, Kanis JA. An estimate of the worldwide prevalence and disability associated with osteoporotic fractures. Osteoporos Int. 2006;17(12):1726-33.

25. Welsh L, Rutherford OM. Hip bone mineral density is improved by high-impact aerobic exercise in postmenopausal women and men over 50 years. Eur J Appl Physiol Occup Physiol. 1996;74(6):511-7.

26. Zehnacker $\mathrm{CH}$, Bemis-Dougherty A. Effect of weighted exercises on bone mineral density in post menopausal women: a systematic review. J Geriatr Phys Ther. 2007;30(2):79-88.

27. Maddalozzo GF, Snow CM. High intensity resistance training: effects on bone in older men and women. Calcif Tissue Int. 2000;66(6):399-404.

28. Marques EA, Gudnason V, Sigurdsson G, Lang T, Johannesdottir F, Siggeirsdottir K. Are bone turnover markers associated with volumetric bone density, size, and strength in older men and women? The AGES-Reykjavik study. Osteoporos Int. 2016;27(5):1765-76. 